\title{
Amalgamation Performances of Gold-Coated Quartz Wool, Alumina, Silica, Sand and Carbon Fiber for the Determination of Inorganic Mercury in Waters by Cold Vapor Atomic Absorption Spectrometry ${ }^{1}$
}

\author{
Arzu Erdem Şimşek ${ }^{a, *}$, Aslı Erdem Yayayürük ${ }^{b}$, Talal Shahwan ${ }^{c}$, and Ahmet E. Eroğlu ${ }^{a}$ \\ ${ }^{a}$ Department of Chemistry, Izmir Institute of Technology, 35430, Urla-İzmir, Turkey \\ ${ }^{b}$ Department of Chemistry, Ege University, 35100, Bornova-Izmir, Turkey \\ ${ }^{c}$ Department of Chemistry, Birzeit University, Ramallah, West Bank, Palestine \\ *e-mail: arzuerdem7@hotmail.com \\ Received February 10, 2016; in final form, September 7, 2016
}

\begin{abstract}
Different gold-coated sorbents for amalgamation were applied for the determination of inorganic mercury in waters using a home-made cold vapor generation unit coupled to atomic absorption spectrometry. Among the gold-coated materials investigated (quartz wool, alumina, silica, sand and carbon fiber) quartz wool was found to give the most efficient results in terms of sorption and release. Analytical performance of the system without and with amalgamation was investigated and it was found that when amalgamation was applied, the linearity and slope of the calibration plots were independent on the sample volume for 1.0, 5.0 and $10.0 \mathrm{~mL}$. Method validation was realized through the analysis of a sample of spring water spiked with $1.0 \mu \mathrm{g} / \mathrm{L}$ inorganic mercury and the spike recoveries were found to be $95 \pm 1,91 \pm 3$, and $99 \pm 5 \%$ for $1.0,5.0$, and $10.0 \mathrm{~mL}$, respectively. The results demonstrated that the methodology can be applied to these types of samples directly or after amalgamation, depending on the mercury concentration.
\end{abstract}

Keywords: mercury, amalgamation, gold-coated sorbents, preconcentration, cold vapor atomic absorption spectrometry

DOI: $10.1134 / \mathrm{S} 1061934817050033$

Mercury is considered as an important contaminant [1]. It is released into the environment as a result of natural and anthropogenic processes [2]. The most important chemical forms are elemental mercury $\left(\mathrm{Hg}^{0}\right)$, inorganic mercury $\left(\mathrm{Hg}^{2+}\right)$, methylmercury $\left(\mathrm{CH}_{3} \mathrm{Hg}^{+}\right)$and dimethylmercury $\left(\mathrm{CH}_{3} \mathrm{HgCH}_{3}\right)$ [3]. The most common and stable form of mercury in waters is the solvated divalent mercuric ion. Although methylmercury is the most toxic form, most of the mercury released into the environment (water, soil and sediments) is inorganic mercury, which can have neurobehavioral effects [4]. Drinking water, fish and fish products are the main routes of incorporation of mercury into the human body [5]. Hence determination and monitoring of mercury in natural waters are of great importance. In drinking water, the World Health Organization [6] recommends a limit of $1 \mu \mathrm{g} / \mathrm{L}$ of mercury whereas the US Environmental Protection Agency [7] establishes a maximum concentration of $2 \mu \mathrm{g} / \mathrm{L}$.

Several methods have been reported for mercury determination in waters [8-10]. Among these cold

\footnotetext{
${ }^{1}$ The article is published in the original.
}

vapor atomic absorption spectrometry (CVAAS) is the most popular technique due to its simplicity, high sensitivity and low cost [11]. Since mercury concentrations in non-polluted waters are very low, there is a still strong need for a sensitive and accurate preconcentration step to monitor mercury in environmental and biological samples. Gold and other precious metals are well known for their high efficiency in trapping $\mathrm{Hg}$ from the gas phase by amalgamation [12, 13]. Goldbased collectors, which are used in many forms such as gold wire in a pyrolytic graphite platform [14], gold-platinum gauze [15], gold-coated sand [16] and gold-coated quartz wool gauze [17] were applied to the preconcentration of $\mathrm{Hg}$ prior to detection.

In the present study, the applicability of different gold-treated amalgamation materials (quartz wool, alumina, silica, sand and carbon fiber) for the collection/determination of inorganic mercury in environmental samples by using CVAAS was examined and analytical performances for the above mentioned materials were compared. The materials synthesized were characterized by scanning electron microscopy (SEM) and energy-dispersive X-ray spectroscopy (EDX). The sorption/release performances of the gold-coated sorbents were examined and the method 


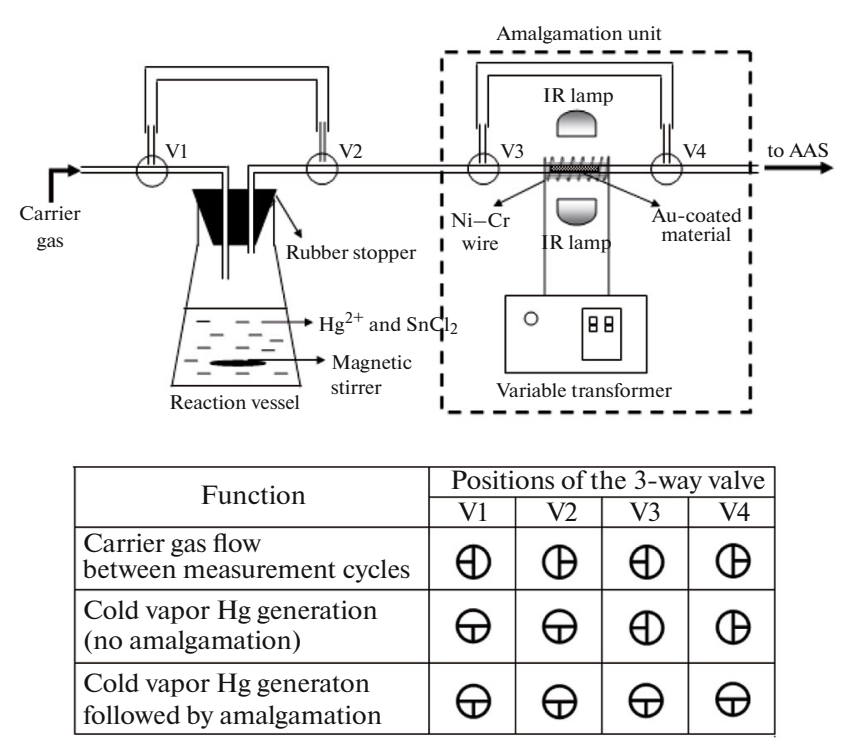

Fig. 1. Home-made cold vapor atomic absorption spectrometry system and the gold amalgamation unit used in mercury determinations (positions of the 3-way valves, V1, $\mathrm{V} 2, \mathrm{~V} 3$ and V4, indicate the flow directions during various steps).

was validated through the spike recovery experiments for a natural spring water sample.

\section{EXPERIMENTAL}

Reagents and chemicals. All reagents were of analytical grade. Ultra pure water $(18 \mathrm{M} \Omega \mathrm{cm})$ was used throughout the study. Glassware and plastic containers were cleaned by soaking in $10 \%$ (v/v) $\mathrm{HNO}_{3}$ (Merck) and rinsed with distilled water prior to use. Mercury intermediate standard solution, $100 \mathrm{mg} / \mathrm{L}$, was prepared from $1000 \mathrm{mg} / \mathrm{L}$ AAS standard in $1 \%$ (v/v) $\mathrm{HNO}_{3}$. Working standards were prepared daily from a second intermediate standard, $100 \mu \mathrm{g} / \mathrm{L}$, by serial dilution in 5\% (v/v) $\mathrm{HNO}_{3}$. A $5 \%(\mathrm{~m} / \mathrm{v}) \mathrm{SnCl}_{2}$ in $0.96 \mathrm{M} \mathrm{HCl}$ (Merck) solution was also prepared daily from $\mathrm{SnCl}_{2} \times 2 \mathrm{H}_{2} \mathrm{O}$ (Merck) by dissolving the appropriate amount of the chemical in water. Gold solution was prepared by dissolving metallic gold obtained from a jewelry shop ( $92 \%$ purity) in aqua regia $\left(\mathrm{HNO}_{3}-\mathrm{HCl}\right)$ on a hot plate $\left(\sim 80^{\circ} \mathrm{C}\right)$.

Instrumentation and apparatus. A Thermo Elemental Solaar M6 Series (Cambridge, UK) atomic absorption spectrometer using a mercury hollow cathode lamp at the wavelength of $253.6 \mathrm{~nm}$ and a deuterium lamp for background correction were employed in all measurements. Mercury determinations were performed by CVAAS, with a $15 \mathrm{~cm}$-long glass absorption cell having quartz windows at both ends mounted on the standard air-acetylene burner head.

The manifold for on-line preconcentration system utilized a $50-\mathrm{mL}$ reaction vessel, a magnetic stirrer to ensure rapid reactions, an amalgamation unit, several 3 -way connectors and Tygon tubings (Fig. 1). In the beginning, the amalgamation unit consisted also of two $150 \mathrm{~W}$ infrared lamps (General Electric Co. USA) to heat the analytical trap. However, it was observed in the initial experiments that heating was not necessary during the amalgamation step as the mercury could be trapped efficiently even at room temperature. Hence, the IR lamps were not used in further experiments. The 3-cm long thermal desorption unit was constructed in the laboratory by wrapping $\mathrm{Ni}-\mathrm{Cr}$ wire about 5 turns per $10 \mathrm{~mm}$. An $8 \mathrm{~A}, 220 \mathrm{VAC}$ input and $45 \mathrm{~V} \mathrm{AC}$ output variable transformer was used to heat the sample trap. The temperature was controlled by a similar design using a $\mathrm{Ni}-\mathrm{Cr}$ thermocouple with a ceramic coated tip. The cold vapor generation and amalgamation systems were under argon atmosphere which also helped in cooling down the heated goldcoated column. In addition to argon gas, two small fans were used to cool the amalgamation unit to room temperature. In a typical run, sample or standard is placed in the $50-\mathrm{mL}$ reaction vessel, $500 \mu \mathrm{L}$ of $5 \%$ $(\mathrm{m} / \mathrm{v}) \mathrm{SnCl}_{2}$ is added with a micropipette, the vessel is closed and the solution is mixed by a magnetic stirrer. After a certain reaction/equilibration time, mercury atoms are formed and then separated from the liquid phase as atomic vapor. An inert gas $\left(\mathrm{N}_{2}\right)$ is passed through the reaction vessel to transport the atomic mercury into the glass absorption tube.

Preparation of the gold-coated sorbents. An appropriate amount of the sorbent (quartz wool, alumina, silica and sand) was weighed and transferred into a porcelain crucible containing $1.5 \mathrm{~mL}$ of $\mathrm{Au}(\mathrm{III})$ solution at various concentrations $(70,175$ and $350 \mathrm{mg} / \mathrm{mL} \mathrm{Au}(\mathrm{III})$ in aqua regia). The mixtures were first heated to dryness on a hot plate to remove excess acids and then placed in a muffle furnace for $2 \mathrm{~h}$ at $560^{\circ} \mathrm{C}$ as described by Magalhaes et al. [18]. The goldcoated sorbents were transferred into a desiccator and cooled to room temperature.

Gold-coated carbon fibers were prepared by sputter-deposition from a gold cathode onto a carbon fiber substrate using Polaron SC7610 model sputter coater (Holland). The sputtering process was performed for both sides of the carbon fibers to obtain a nearly homogeneous coating. The blank samples for the above mentioned materials were also prepared in the same manner to compare the trapping efficiency of the uncoated and the gold-coated surfaces. In the amalgamation unit, $0.3-\mathrm{cm}$ i.d. quartz tubes were filled with the gold-coated sorbents $(0.2 \mathrm{~g}$, approximately $0.5-\mathrm{cm}$ length) and untreated quartz wool was used as stoppers at column ends.

\section{RESULTS AND DISCUSSION}

Characterization of the gold-based collectors. The SEM (Philips XL-30S FEG) back-scattered microim- 

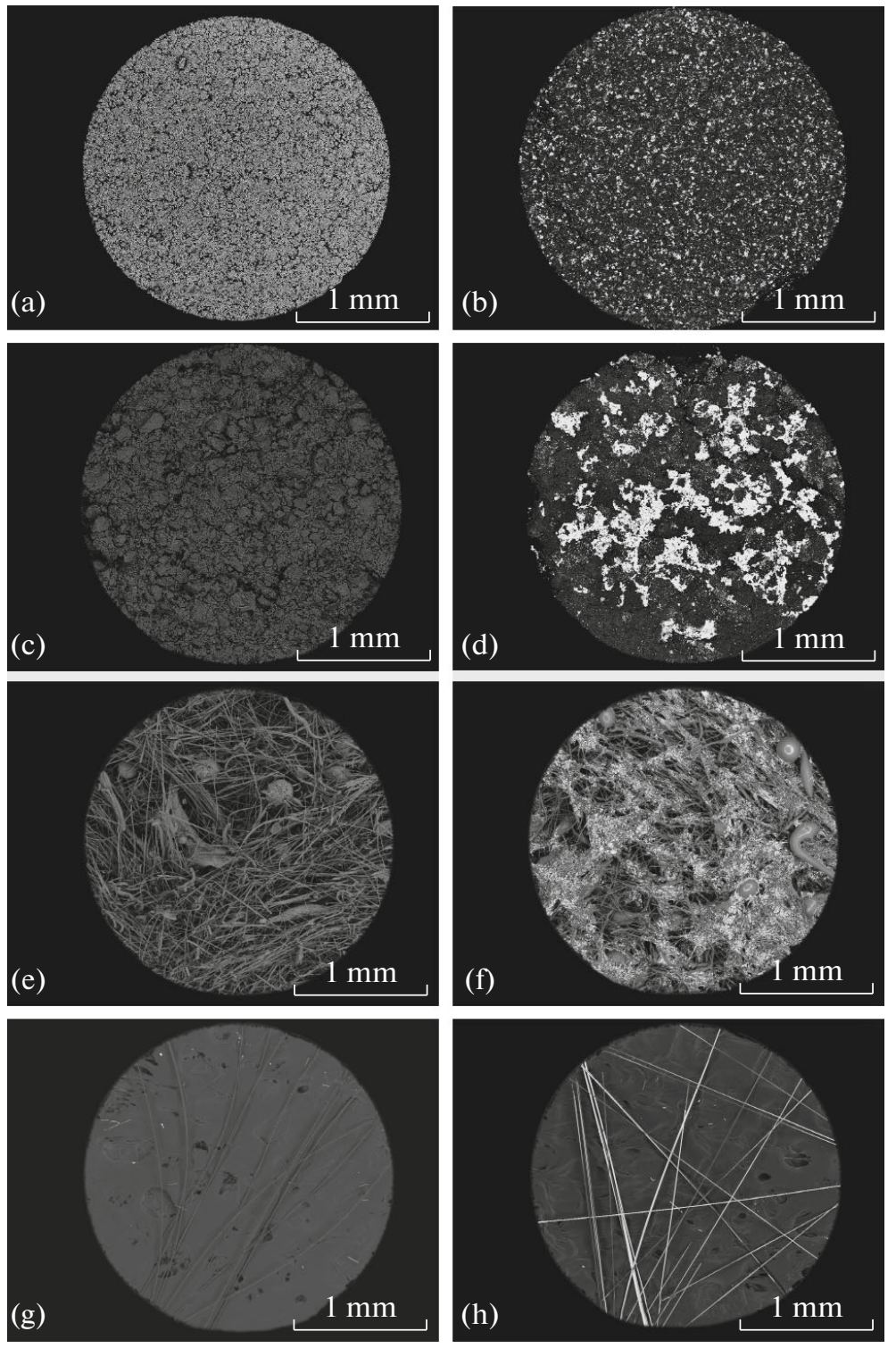

Fig. 2. Scanning electron microscopy back-scattered microimages of untreated alumina (a), gold-coated alumina (b), untreated silica (c), gold-coated silica (d), untreated quartz wool (e), gold-coated quartz wool (f), untreated carbon fibers (g), gold sputtercoated carbon fibers $(\mathrm{h})$ after $36 \times$ magnification.

ages of the untreated and gold-coated (with $350 \mathrm{mg} / \mathrm{mL} \mathrm{Au}(\mathrm{III})$ solution) alumina/silica surfaces are shown in Figs. 2a-2d. Among the Au(III) concentrations investigated $(70,175$, and $350 \mathrm{mg} / \mathrm{mL})$, only $350 \mathrm{mg} / \mathrm{mL}$ resulted in an appreciable gold coating on the surfaces. A less uniformly distributed surface and a kind of coagulation of gold particles was observed for gold-coated silica which might led to irreproducible results for silica. When the SEM back-scattered microimages of the untreated and gold-coated quartz wool surfaces are investigated (Figs. 2e, 2f), it was clearly seen that 175 and $350 \mathrm{mg} / \mathrm{mL}$ gold-coated quartz wool samples showed similar (and relatively homogeneous) coverings, however, $350 \mathrm{mg} / \mathrm{mL}$ goldcoated quartz wool was used in the remaining experi- ments as this material demonstrated the most efficient behavior in terms of mercury trapping. The EDX results (not shown) confirmed the same observation; the amount of gold coated on the surface was higher when $350 \mathrm{mg} / \mathrm{mL}$ Au(III) solution was used in the coating step. The SEM microimages of uncoated and sputter-coated carbon fibers (Figs. 2g, 2h) and goldcoated sand (not shown) have also acceptable coatings on the surfaces.

Optimization of the trapping temperature of the gold-based collectors. The trapping temperature of the gold-coated sorbents was determined with $20.0 \mathrm{ng}$ $\mathrm{Hg}(\mathrm{II})$ in $0.7 \mathrm{M} \mathrm{HNO}_{3}$ using the usual analysis procedure. After the addition of $500 \mu \mathrm{L}$ of $5 \%(\mathrm{~m} / \mathrm{v}) \mathrm{SnCl}_{2}$ 


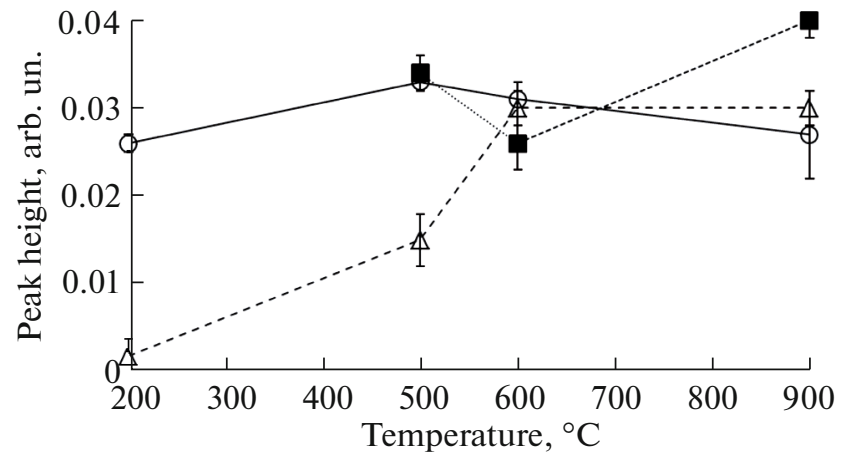

Fig. 3. Effect of releasing temperature on mercury signal with amalgamation materials coated with $350 \mathrm{mg} / \mathrm{mL}$ Au(III) solution: (ם) - gold-coated alumina, $(\triangle)$ - goldcoated silica, $(\bigcirc)$ - gold-coated quartz wool; $0.7 \mathrm{M}$ $\mathrm{HNO}_{3} ; 500 \mu \mathrm{L}$ of $5 \%(\mathrm{~m} / \mathrm{v}) \mathrm{SnCl}_{2} ; n=3$.

solution, $\mathrm{Hg}^{2+}$ was reduced to $\mathrm{Hg}^{0}$ and the generated atomic mercury vapor was passed through the goldcoated collectors. At the initial stages of the study, attempts were made to optimize the trapping temperature and it was found that all the gold-coated amalgamation materials investigated were very efficient $(>95 \%)$ in the sorption of atomic mercury vapor even at room temperature $\left(\sim 25^{\circ} \mathrm{C}\right)$. Therefore, the higher trapping temperatures were not applied in the subsequent parts of the study.

Optimization of the releasing temperature of the gold-based collectors. The change in mercury signal as a function of releasing temperature obtained with alumina is shown in Fig. 3a. Mercury signal increased with the increase in the releasing temperature up to $600^{\circ} \mathrm{C}$. At $500^{\circ} \mathrm{C}$, a second peak was observed due to consecutive heating cycles indicating the inefficiency of this temperature to release mercury quantitatively. In addition to this, relatively higher standard deviations were observed for releasing temperatures below $400^{\circ} \mathrm{C}$. When the temperature was at $600^{\circ} \mathrm{C}$, the release from the sorbent was quantitative. Since a similar absorbance signal was obtained at a higher temperature $\left(900^{\circ} \mathrm{C}\right)$, use of a release temperature of $600^{\circ} \mathrm{C}$ can be suggested for optimum results. In addition, no memory effect was observed above $600^{\circ} \mathrm{C}$. An interesting behavior was observed with alumina blank (treated only with aqua regia in the same manner) in such a way that the mercury vapor generated in the reaction vessel was adsorbed by alumina; but it could not be desorbed from the column even at the maximum possible temperature $\left(900^{\circ} \mathrm{C}\right)$. This finding implies a strong interaction between the mercury vapor and the alumina surface, can be a topic of further studies. However the small particle size of the alumina was not very suitable for the amalgamation column and caused significant back pressure that does not fit the purpose of this study. When the results of the desorption study for gold-coated silica (Fig. 3b) were considered, it was observed that a very high tem- perature (maybe $>900^{\circ} \mathrm{C}$ ) must be applied in order to release mercury from the column. The blank silica trapped approximately one-fourth of the total mercury generated in the reaction vessel. Similar to alumina, the small particle size of the silica used caused significant back pressure and, therefore, did not fit the purpose of this study. When quartz wool was investigated (Fig. 3c) for the change in mercury signal as a function of release temperature, even a temperature of $200^{\circ} \mathrm{C}$ resulted in the release of most of the mercury, but a temperature of $500^{\circ} \mathrm{C}$ was applied for the quantitative release of mercury from the sorbent. The reproducibility of the results was very good; in addition, no memory effect was observed as all the trapped mercury was quickly released from the column. A very important advantage, on the other hand, of quartz wool over the other materials was the ease of operation during the preparation of the experiments. The gold sputter-coated carbon fiber was also very efficient for trapping $(>80 \%)$ even at room temperature. Practically, it was superior to alumina and silica, but inferior to quartz wool. Its releasing behavior was very similar to quartz wool and a temperature of $500^{\circ} \mathrm{C}$ was applied at the desorption step. The performance of the gold sputter-coated carbon fiber will be investigated and improved as a future work. Mercury vapor was also retained by gold-coated sand; however, difficulties arose upon its release at various temperatures. When commercially available gold-coated sand was tried, the same troubles appeared as well and no reliable results were obtained within the experimental conditions applied for gold-coated quartz wool. After all, it is apparent that, under the circumstances applied in this work, gold-coated quartz wool demonstrated the most promising behavior in mercury amalgamation and therefore the remaining experiments were carried out with this material. However, the authors believe that further elaboration of the topic is still required in a separate study.

Calibration plot for gold-coated quartz wool. The linear equations and correlation coefficients for the calibration of inorganic mercury in the range of 1.0 to $20.0 \mathrm{ng}$ (sample volume of $2.5 \mathrm{~mL}$ ) are $y=0.0012 x-$ $0.0003, R^{2}=0.9979$ and $y=0.0019 x-0.0007, R^{2}=$ 0.9868 , without and with amalgamation, respectively. About $60 \%$ higher sensitivity was obtained with amalgamation under the experimental conditions employed. The mercury signal without amalgamation has a wider peak width at the half maximum, whereas it becomes sharper after amalgamation. This must be due to the release of mercury from a smaller volume and the transfer of the released mercury vapor to the absorption tube without much dilution with the carrier gas. Also, rapid heating could increase the rate of mercury released from the amalgamation column. The sensitivities with amalgamation were also enhanced with the other materials tested (data not shown) but it was more pronounced in the case of quartz wool. 
The cumulative sorption performance of the goldcoated quartz wool was tested with different trapping factors (Table 1). In the first cycle, $20.0 \mathrm{ng}$ mercury was trapped and then released in one run (reference value). In the second run, $10.0 \mathrm{ng}$ mercury was trapped twice in a consecutive manner and the deposited mercury was then released as before. In the third run, $4.0 \mathrm{ng}$ mercury was trapped five times consecutively and released afterwards. The absolute amount of mercury was $20.0 \mathrm{ng}$ in all cases. According to the results given in Table 1, it can be said that trapping/releasing steps are acceptable $(>90 \%)$ at least for a preconcentration factor of five.

Analytical performance of the CVAAS system. Effect of sample volume on sensitivity. The effect of sample volume on sensitivity (without amalgamation) was investigated using volumes of $2.0,5.0$, and $10.0 \mathrm{~mL}$. For this purpose, various concentrations of $\mathrm{Hg}^{2+}$ $(0.1-10 \mu \mathrm{g} / \mathrm{L})$ were prepared at the above-mentioned volumes and determined using the optimum conditions. It was observed that the mercury signal increases with increasing sample volume (data not shown). All three volumes can be applied for quantitative determination of mercury in many environmental samples. In terms of repeatability of the results and for the convenience of the reaction in the present $50-\mathrm{mL}$ reaction vessel, $2.0 \mathrm{~mL}$ sample volume offered the best results. On the other hand, 5.0 and $10.0 \mathrm{~mL}$ sample volumes (or, even larger volumes with a higher-volume reaction vessel) can be suggested if more sensitive results are required.

In order to investigate the effect of sample volume on sensitivity (with amalgamation), different $\mathrm{Hg}^{2+}$ concentrations and different sample volumes were employed. Mercury concentrations and the sample volumes were varied between $0.1-5.0 \mu \mathrm{g} / \mathrm{L}$ and $2.0-10.0 \mathrm{~mL}$, respectively. The absorbance was plotted as a function of absolute amount of mercury (data not shown). It was observed that all three volumes can be applied for quantitative determination of mercury after amalgamation due to the similarity of the calibration plots obtained. Within the studied range, it is seen that, with amalgamation, the linearity of the calibration plots was not dependent on the sample volume and this property is expected to offer an important advantage since it makes the volume adjustment unnecessary.

Effect of sample volume on limit of detection. As mentioned before, the purpose of this study was to investigate the applicability of different amalgamation materials as a part of a home-made cold vapor generation unit coupled to AAS. Therefore, the comparison was made among the amalgamation materials investigated rather than between the above-mentioned systems and those described in the literature. Here, standard $\mathrm{Hg}^{2+}$ solutions with the indicated concentrations were prepared and the limit of detection (LOD) based on $3 \mathrm{~s}$ criterion for each sample volume was calculated before
Table 1. Efficiency of the gold-coated quartz wool in consecutive trapping steps (total amount of $\mathrm{Hg}$ was $20.0 \mathrm{ng}$ in all cases, $n=3$ )

\begin{tabular}{c|c|c}
\hline $\begin{array}{c}\text { Initial amount } \\
\text { of } \mathrm{Hg}, \text { ng }\end{array}$ & $\begin{array}{c}\text { Number } \\
\text { of trapping cycles }\end{array}$ & $\begin{array}{c}\text { Relative } \\
\text { recovery, \% }\end{array}$ \\
\hline 20.0 & 1 & $100 \pm 1$ \\
10.0 & 2 & $102 \pm 2$ \\
4.0 & 5 & $91 \pm 5$ \\
\hline
\end{tabular}

Table 2. Limits of detection for different sample volumes without and with five-times-trap amalgamation $(n=3)$

\begin{tabular}{c|c|c|c}
\hline \multirow{2}{*}{$\begin{array}{c}\text { Volume, } \\
\mathrm{mL}\end{array}$} & $\begin{array}{c}\text { Concentration, } \\
\mu \mathrm{g} / \mathrm{L}\end{array}$ & \multicolumn{2}{|c}{ Limit of detection, $\mu \mathrm{g} / \mathrm{L}$} \\
\cline { 3 - 4 } & & $\begin{array}{c}\text { without } \\
\text { amalgamation }\end{array}$ & $\begin{array}{c}\text { with } \\
\text { amalgamation }\end{array}$ \\
\hline 2.0 & 0.2 & 0.052 & 0.015 \\
5.0 & 0.1 & 0.028 & 0.019 \\
10.0 & 0.1 & 0.027 & 0.020 \\
\hline
\end{tabular}

Table 3. Spike recovery results of Karaburun spring water for gold-coated quartz wool $(n=3)$

\begin{tabular}{|c|c|c|c|}
\hline \multirow{2}{*}{$\begin{array}{c}\text { Volume, } \\
\text { mL }\end{array}$} & \multirow{2}{*}{$\begin{array}{c}\text { Spiked } \\
\text { concentration, } \\
\mu \mathrm{g} / \mathrm{L}\end{array}$} & \multicolumn{2}{|c|}{ Recovery, \% } \\
\hline & & $\begin{array}{c}\text { without } \\
\text { amalgamation }\end{array}$ & $\begin{array}{c}\text { with } \\
\text { amalgamation }\end{array}$ \\
\hline 1.0 & - & $<$ LOD & $<$ LOD \\
\hline 1.0 & 1.0 & $95 \pm 1$ & $96 \pm 4$ \\
\hline 5.0 & 1.0 & $91 \pm 3$ & $93 \pm 2$ \\
\hline 10.0 & 1.0 & $99 \pm 5$ & $96 \pm 4$ \\
\hline
\end{tabular}

and after amalgamation ( 5 times trapping). The amalgamation step improves LOD for each sample volume, with the highest improvement on $2.0 \mathrm{~mL}$ (Table 2). The LOD values obtained (15-20 ng/L) are relatively low compared to norms recommended by World Health Organization $(1 \mu \mathrm{g} / \mathrm{L})$ for drinking water which guarantees the applicability of the gold-coated quartz wool as an amalgamation material in the homemade cold vapor generation unit described.

Application to a real sample. As demonstrated in the previous sections, the sample volume is a very crucial parameter that has a direct influence on the sensitivity of the method without amalgamation. In order to investigate the effect of the volume of a sample with amalgamation, spring water collected from Karaburun (a town in İzmir, Turkey) was spiked with $1.0 \mu \mathrm{g} / \mathrm{L}$ $\mathrm{Hg}^{2+}$ and the proposed method was employed. The spike recovery results given in Table 3 demonstrated the applicability of the gold-coated quartz wool with amalgamation method to the samples with low mercury concentrations. 


\section{CONCLUSIONS}

An amalgamation unit utilizing various goldcoated sorbents was constructed and employed in the determination of inorganic mercury in waters. Among the gold-coated amalgamation materials investigated, quartz wool was found to be the most efficient in terms of both trapping and release. The linearity and the slope of the calibration plots were not dependent on the sample volume which is an important advantage since it makes the volume adjustment unnecessary within the experimental conditions applied in the study. Moreover the LOD was 3.5 times lower than that without amalgamation when 5-times trapping were employed. High recovery results obtained for a spring water sample indicated the applicability of the method in inorganic mercury determinations.

\section{ACKNOWLEDGMENTS}

The authors would like to acknowledge the Center for Materials Research at İzmir Institute of Technology for the SEM-EDX facilities, Prof. Dr. Osman Yavuz Ataman, Prof. Dr. Nusret Ertaş and Assoc. Prof. Dr. Sezgin Bakırdere for their helps in the construction of cold vapor generation and amalgamation systems used in this study.

\section{REFERENCES}

1. Dakova, I., Karadjova, I., Georgieva, V., and Georgiev, G., Talanta, 2009, vol. 78, p. 523.

2. Hamza, A., Bashammakh, A.S., AlSibaai, A.A., Al Saidi, H.M., and El Shahawi, M.S., J. Hazard. Mater., 2010, vol. 178, p. 287.
3. Andac, M., Mirel, S., Senel, S., Say, R., Ersoz, A., and Denizli, A., Int. J. Biol. Macromol., 2007, vol. 40, p. 159.

4. Stanisz, E., Justyna Werner, J., and Matusiewicz, H., Microchem. J., 2013, vol. 110, p. 28.

5. Soleimani, M. and Afshar, M.G., J. Anal. Chem., 2015, vol. 70 , no. 1 , p. 5 .

6. Environmental Protection Agency, 2010, vol. 75, no. 59, p. 15504.

7. European Union (Drinking Water) Regulations, 2014, S.I. no. 122.

8. Alonso, E.V., Cordero, M.T.S., Torres, A.G., Rudner, P.C., and Pavon, J.M.C., Talanta, 2008, vol. 77, p. 53.

9. Geng, W., Nakajima, T., Takanashi, H., and Ohki, A., J. Hazard. Mater., 2008, vol. 154, p. 325.

10. Yayayuruk, O., Henden, E., and Bicak, N., Anal. Sci., 2011, vol. 27, no. 8, p. 833.

11. Welz, B. and Sperling, M., Atomic Absorption Spectrometry, Weinheim: Wiley, 1999, 3rd ed.

12. Labatzke, T. and Schlemmer, G., Anal. Bioanal. Chem., 2004, vol. 378, no. 4, p. 1075.

13. Zierhut, A., Leopold, K., Harwardt, L., Worsfold, P., and Schuster, M., J. Anal. At. Spectrom., 2009, vol. 24, no. 6, p. 767.

14. Rivaro, P., Ianni, C., Soggia, F., and Frache, R., Microchim. Acta, 2007, vol. 158, p. 345.

15. Cossa, D., Sanjuan, J., Cloud, J., Stockwell, P.B., and Corns, W.T., J. Anal. At. Spectrom., 1995, vol. 10, p. 287.

16. Liang, L. and Bloom, N.S., J. Anal. At. Spectrom., 1993, vol. 8, p. 591.

17. Aeschliman, D.B. and Norton, G.A., Environ. Sci. Technol., 1999, vol. 33, p. 2278.

18. Magalhaes, C.E.C., Krug, F.J., Fostier, A.H., and Berndt, H., J. Anal. At. Spectrom., 1997, vol. 12, p. 1231. 